\title{
Electrolyte for quantum dot-sensitized solar cells assessed with cyclic voltammetry
}

\author{
Fumin $\operatorname{Ren}^{1 *}$, Sujun $\mathrm{Li}^{1}$ and Chenglei $\mathrm{He}^{2}$
}

\begin{abstract}
An intuitive method was designed to measure the performance of various electrolytes for quantum dot-sensitized solar cells (QDSSCs). Cyclic voltammetry (CV) measurements were used to evaluate the electrolyte performance using a standard three-electrode system composed of a working electrode, counter electrode, and reference electrode. $\mathrm{CV}$ measurements were carried out over the potential range of -0.7 to $-0.1 \mathrm{~V}$ at a scan rate of $50 \mathrm{mV} \mathrm{s}^{-1}$ in five different polysulfide electrolytes. A higher reduction peak current in the $\mathrm{CV}$ curve indicated a faster rate of the redox reaction $\left(S_{n}^{2-}\right.$ to $\left.S^{2-}\right)$ in the electrolyte. The QDSSCs were assembled into a sandwich structure consisting of a CdS/CdSe co-sensitized photoanode, a PbSe counter electrode, and a polysulfide electrolyte. Photocurrent density vs. voltage curves were measured for the assembled cells. The resulting energy conversion efficiency measurements were consistent with the $\mathrm{CV}$ results. An energy conversion efficiency of $\mathbf{5 . 1 4 \%}$ was obtained for QDSSCs using an electrolyte containing 0.05 M 1,2-dimethyl-3-propylimidazolium iodide.
\end{abstract}

\section{INTRODUCTION}

Quantum dot-sensitized solar cells (QDSSCs) show great potential for future applications, because of their high efficiency and low cost [1,2]. As an essential part of the socalled sandwich structure solar cells, the electrolyte plays the important roles of facilitating electron transfer and completing the cell's electronic circuit with the aid of a redox couple $[3,4]$. Iodide/triiodide $\left(\mathrm{I}^{-} / \mathrm{I}^{3-}\right)$ is the most commonly used electrolyte redox couple in dye-sensitized solar cells [5]. Unfortunately, the $\mathrm{I}^{-} / \mathrm{I}^{3-}$ couple is not suitable for QDSSCs, because it causes corrosion and photodegradation of quantum dots (QDs) [6,7]. For this reason, polysulfide redox couples $\left(\mathrm{S}^{2-} / \mathrm{S}_{n}^{2-}\right)$ are often used in QDSSCs to achieve acceptable photon-to-current conversion efficiencies without QD degradation [8-10]. Currently, the photoelectric conversion efficiency of QDSSCs is still lower than that obtained using dye-sensitized solar cells [11]. While most efforts to improve QDSSCs have focused on developing new QD sensitizers and counter electrodes (CEs), studies on the role of different electrolytes for QDSSCs were

\author{
few $[9,12]$.
}

The limited number of reports on the electrolytes used in QDSSCs may be caused by the difficulty of evaluating QDSSC performance, which is characterized by several parameters, such as short circuit current density, open circuit voltage, and fill factor (FF). At the same time, the concentration of electrolyte components varies between studies, making it difficult to reliably compare the reported efficiencies of different QDSSCs [13-17]. The current density that a solar cell can achieve might also be measured using cyclic voltammetry (CV). Accordingly, we developed an instructive method to evaluate the performance of QDSSCs containing different electrolytes using CV measurements. This method was applied to different electrolytes, providing meaningful results for the comparison of solar cells.

In this work, we analyzed the performance of solar cells containing five different electrolytes using CV measurements. Electrolytes that have a higher current in $\mathrm{CV}$ measurements also produce a higher photocurrent density, $J_{\text {sc }}$, when used in an assembled QDSSC. Electrochemical impedance spectroscopy provides further insight into electrolyte performance. When 1,2-dimethyl-3-propylimidazolium iodide (DMPII) is added to the electrolyte, both the cell performance and the cathodic peak current measured with CV increase. Using an improved electrolyte formulation, a cell efficiency of $5.14 \%$ is achieved for CdS/CdSe co-sensitized QDSSCs.

\section{EXPERIMENTAL}

\section{Preparation of the electrolytes}

We prepared five kinds of traditional polysulfide electrolytes consisting of $\mathrm{Na}_{2} \mathrm{~S}, \mathrm{~S}$ and various additives in a methanol/water (7:3, v:v) mixture, as shown in Table 1.

Preparation of CdS/CdSe co-sensitized photoanodes Fluoride doped tin oxide (FTO) glass $(7 \Omega$ ) was used as the substrate for photoanode preparation. The doctor-blade

\footnotetext{
${ }^{1}$ Department of Municipal and Environment Engineering, Beijing Jiaotong University, Beijing 100044, China

${ }^{2}$ School of Materials Science \& Engineering, Shaanxi Normal University, Xi'an 710620, China

* Corresponding author (email: renfumin2004@sina.com.cn)
} 
Table 1 Composition of different electrolytes

\begin{tabular}{cccc}
\hline Electrolyte & $\mathrm{Na}_{2} \mathrm{~S}$ & $\mathrm{~S}$ & Additives \\
\hline $\mathrm{a}$ & $2 \mathrm{M}$ & $2 \mathrm{M}$ & $0.2 \mathrm{M} \mathrm{KCl}$ \\
$\mathrm{b}$ & $1 \mathrm{M}$ & $2 \mathrm{M}$ & $0.4 \mathrm{M} \mathrm{KCl}$ \\
$\mathrm{c}$ & $2 \mathrm{M}$ & $0.5 \mathrm{M}$ & $0.2 \mathrm{M} \mathrm{KCl}$ \\
$\mathrm{d}$ & $1 \mathrm{M}$ & $1 \mathrm{M}$ & $0.1 \mathrm{M} \mathrm{NaOH}$ \\
$\mathrm{e}$ & $0.5 \mathrm{M}$ & $2 \mathrm{M}$ & $0.2 \mathrm{M} \mathrm{KCl}$ \\
\hline
\end{tabular}

method was used to coat the FTO glass with a prepared $\mathrm{TiO}_{2}$ paste. The active area of the resulting surface was about $0.283 \mathrm{~cm}^{2}$. The $\mathrm{TiO}_{2}$-coated FTO was then sintered at $450^{\circ} \mathrm{C}$ for $30 \mathrm{~min}$. Successive ionic layer adsorption and reaction (SILAR) and chemical bath deposition (CBD) were used to deposit CdS/CdSe QDs on the nanocrystalline thin film electrode, as described previously [18]. This deposition was performed using a $0.1 \mathrm{M} \mathrm{Cd}\left(\mathrm{NO}_{3}\right)_{2}$ methanol solution, a $0.1 \mathrm{M} \mathrm{Na}_{2} \mathrm{~S}$ methanol/water (1:1, v:v) solution, and a $0.03 \mathrm{M}$ sodium selenosulfate $\left(\mathrm{Na}_{2} \mathrm{SeSO}_{3}\right)$ aqueous solution as the $\mathrm{Cd}, \mathrm{S}$, and Se sources, respectively. The $\mathrm{Na}_{2} \mathrm{SeSO}_{3}$ solution was prepared by dissolving $\mathrm{Se}$ powder $(0.03 \mathrm{M})$ in an aqueous solution of $\mathrm{Na}_{2} \mathrm{SO}_{3}(0.06$ $\mathrm{M})$ at $97^{\circ} \mathrm{C}$ for $3 \mathrm{~h}$. The photoanode film was immersed in $\mathrm{Cd}\left(\mathrm{NO}_{3}\right)_{2}$ solution for $1 \mathrm{~min}$, rinsed with methanol, and dried for $2 \mathrm{~min}$, before being immersed in $\mathrm{Na}_{2} \mathrm{~S}$ solution for $1 \mathrm{~min}$, rinsed with methanol, and dried for $2 \mathrm{~min}$. This cycle was repeated five times. CdSe QDs were then deposited on the CdS-sensitized films by CBD method at $50^{\circ} \mathrm{C}$. The CdS-sensitized electrode was dipped into the $\mathrm{Cd}\left(\mathrm{NO}_{3}\right)_{2}$ solution for $10 \mathrm{~min}$, rinsed with methanol and dried for $2 \mathrm{~min}$. The resulting electrode was then dipped into the $\mathrm{Na}_{2} \mathrm{SeSO}_{3}$ solution for $20 \mathrm{~min}$, rinsed with distilled water and dried for $2 \mathrm{~min}$. The process was repeated for up to 7 cycles. Finally, a $\mathrm{ZnS}$ passivation layer was formed on the sensitized photoanodes by first immersing the electrode in a $0.1 \mathrm{M} \mathrm{Zn}\left(\mathrm{CH}_{3} \mathrm{COO}\right)_{2}$ methanol solution and rinsing with methanol before immersing the electrode in a $0.1 \mathrm{M} \mathrm{Na}_{2} \mathrm{~S}$ aqueous solution for $1 \mathrm{~min}$ and rinsing with distilled water $[19,20]$.

\section{Preparation of the PbSe CEs}

An electroplating method was used to create a PbSe CE. First, 6.7 g ethylenediaminetetraacetic acid (EDTA) was dissolved in distilled water. The $\mathrm{pH}$ of this solution was adjusted to $\mathrm{pH} 7-8$ by adding $3 \mathrm{~mL}$ of $3 \mathrm{M} \mathrm{NaOH}$. Then, 3.4 $\mathrm{g} \mathrm{Pb}\left(\mathrm{CH}_{3} \mathrm{COO}\right)_{2}$ and $20 \mathrm{~mL} \mathrm{Na}_{2} \mathrm{SeSO}_{3}$ solution were added to provide the $\mathrm{Pb}$ and Se sources. A Maynuo DC source meter (M8811 $30 \mathrm{~V} / 5 \mathrm{~A}$ ) was used to electroplate PbSe onto FTO glass. A graphite electrode was used as the cathode, and a clean FTO glass substrate was used as the anode.
Electroplating was performed for $4 \mathrm{~s}$ with a pulse voltage of $3 \mathrm{~V}$ and a current of $5 \mathrm{~A}$.

\section{Fabrication of QDSSCs}

To assemble QDSSCs, prepared photoelectrodes and CEs were sealed with a $50 \mu \mathrm{m}$ thick hot melt-sealing sheet. Polysulfide electrolytes were filled through holes, which were drilled in the cell.

\section{Characterization}

To study the impact of electrolyte on cell performance, cyclic voltammetry was performed using a CHI660d electrochemical workstation and a conventional three-electrode system consisting of a glassy carbon disc (3 mm diameter) working electrode, $\mathrm{Ag} / \mathrm{AgCl}$ reference electrode, and platinum CE [5]. Measurements were performed at $20^{\circ} \mathrm{C}$ in the potential range of -0.7 to $-0.1 \mathrm{~V}$ at a scan rate of 50 $\mathrm{mV} \mathrm{s}^{-1}$. Prior to each test, the glassy carbon electrode was hand polished with submicrometer alumina and washed with deionized water, following a procedure demonstrated to have good reproducibility [21]. The photocurrent-voltage characteristics of the QDSSCs were measured using a CHI660d electrochemical workstation under $100 \mathrm{mV} \mathrm{cm}^{-2}$ AM 1.5G illumination provided by a solar simulator. Electrochemical impedance spectroscopy (EIS) was performed under open-circuit conditions over the frequency range from $0.1 \mathrm{~Hz}$ to $10^{6} \mathrm{~Hz}$ at room temperature in the dark.

\section{RESULTS AND DISCUSSION}

Typical cyclic voltammograms obtained in five different polysulfide electrolytes (electrolytes a-e) are shown in Fig. 1a. The current increases with the increases in the electrode potential. In addition, different current magnitudes are obtained in each electrolyte. In the CV curves, the current obtained at more negative potentials, is the result of the reduction of $S_{n}^{2-}$ to $S^{2-}$ [22]. The reduction current peaks reflect the catalytic reduction of $S_{n}^{2-}$ at the CE. A higher cathodic peak current represents a faster redox reaction rate in the electrolyte [23-25]. Although other parameters such as ion migration rate can influence current magnitude, these effects cannot be directly extracted from CV curves. In order to simplify the interpretation of $\mathrm{CV}$ data, we tend to relate cathodic peak current values from $\mathrm{CV}$ curves directly to the photocurrent density $\left(J_{\text {sc }}\right)$, achieved by QDSSCs.

To demonstrate whether a higher current in CV measurements of different electrolytes implies a higher $J_{\mathrm{sc}}$ in QDSSCs containing the same electrolyte, we assembled QDSSCs with the CdS/CdSe co-sensitized $\mathrm{TiO}_{2}$ photoelectrode and $\mathrm{PbSe} \mathrm{CE}$ based on the polysulfide electrolyte. Fig. $1 \mathrm{~b}$ shows the $J-V$ curves of the QDSSCs using different 

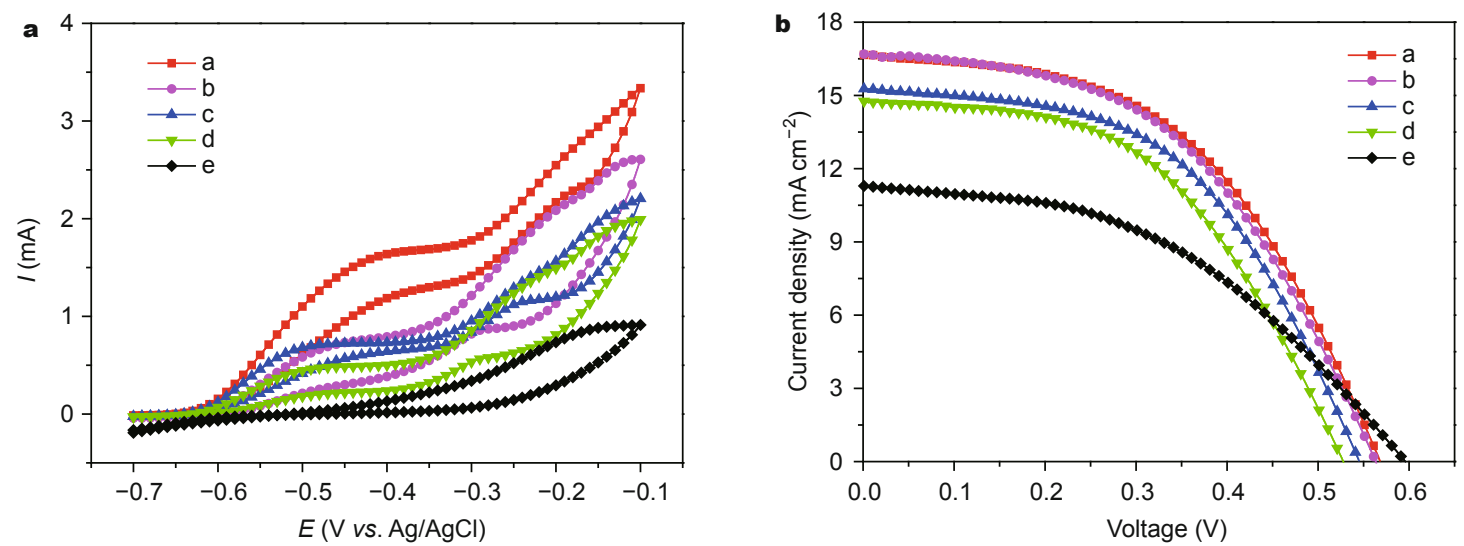

Figure 1 (a) Cyclic voltammograms of the prepared electrolytes using a three electrode system at a scan rate of $50 \mathrm{mV} \mathrm{s} \mathrm{s}^{-1}$; (b) photocurrent density-voltage $(J-V)$ curves based on the $\mathrm{CdS} / \mathrm{CdSe}$ co-sensitized $\mathrm{TiO}_{2}$ film and $\mathrm{PbSe} \mathrm{CE}$ using five different electrolytes under one-sun illumination $(\mathrm{AM}$ $\left.1.5 \mathrm{G}, 100 \mathrm{mV} \mathrm{cm}^{-2}\right)$.

electrolytes. Cell parameters, including the $J_{\text {sc }}$, open circuit $\left(V_{\mathrm{oc}}\right), \mathrm{FF}$, and power conversion efficiency $(\eta)$ are summarized in Table 2 . The FF is defined as the ratio of maximum output power to the product of $V_{\mathrm{oc}}$ and $J_{\mathrm{sc}}$, which is an important parameter. The present $\eta$ values are higher than those found in the literature [13-17], partially due to the improvements in the competing CE. As shown in Table 2, $J_{\mathrm{sc}}$ varies in the same manner as the cathodic peak current in $\mathrm{CV}$ curves, such that $J_{\mathrm{sc}}$ increases with increasing current in the independent $\mathrm{CV}$ measurements. Although the present $J_{\text {sc }}$ sequence is different from that reported in the literature, it is believed that the observed $J_{\mathrm{sc}}$ sequence is reasonable, because all of the cell parameters are determined using the same CE in this study. It is apparent that QDSSCs containing electrolyte a have the highest efficiency and the highest $J_{\text {sc }}$ among the cells.

Meanwhile, the Nyquist plots and the Bode phase plots of electrolytes are shown in Fig. 2. The equivalent circuit of the cell is depicted in the inset of Fig. $2 \mathrm{a}$. The equivalent circuit includes a series resistance $\left(R_{1}\right)$ in the high-frequency region and the resistance capacitance processes at the electrode/electrolyte interface, which consist of the charge transfer resistance $\left(R_{2}\right)$ and the electrical double layer capacitance (CPE1) in the medium-frequency region. Anoth- er circuit component accounts for mass transport processes including Nernst diffusion $\left(R_{3}\right)$ of the $n \mathrm{~S}^{2-} / \mathrm{S}_{n}^{2-}$ redox couple and capacitance (CPE2) in the low frequency region [23]. The internal impedances determined from EIS analysis, resistance values $\left(R_{1}, R_{2}, R_{3}\right)$, and electron recombination lifetimes $(\tau)$ are also listed in Table 2 . The charge lifetime is calculated using Equation (1), where $f_{\text {mid }}$ is the maximum frequency in the Bode phase plot [26].

$$
\tau=1 /\left(2 \pi f_{\text {mid }}\right) .
$$

The value of $R_{1}$ is determined by the resistance of the FTO layer, the electrode, and the electrolyte. The value of $R_{2}$ between the CE and electrolyte is typically interpreted as an indication of the extent of electrocatalytic activity. A smaller $R_{2}$ facilitates electron transfer from CE to electrolyte for the catalytic reduction of $\mathrm{S}_{n}^{2-}$ to $\mathrm{S}^{2-}$ and, consequently, results in less interfacial recombination [27]. The $R_{2}$ value ranges from $4.39 \Omega \mathrm{cm}^{2}$ for the cell with electrolyte a to $37.06 \Omega \mathrm{cm}^{2}$ for the cell with electrolyte e, which is in agreement with the observations of decreasing cathodic peak currents during CV measurements.

To validate the relationship between the cathodic peak current from CV measurements and the $J_{\text {sc }}$ obtained by QDSSCs, 0.05 M DMPII was added to electrolyte a to en-

Table 2 Photovoltaic performance parameters, the fitted parameters extracted from the impedance spectra in Fig. 2, and the electronic properties of $\mathrm{CdS} / \mathrm{CdSe}$ co-sensitized $\mathrm{TiO}_{2}$ film and $\mathrm{PbSe} \mathrm{CE}$ with different types of electrolytes

\begin{tabular}{|c|c|c|c|c|c|c|c|c|}
\hline electrolyte & $J_{\mathrm{sc}}\left(\mathrm{mA} \mathrm{cm}^{-2}\right)$ & $V_{\mathrm{oc}}(\mathrm{V})$ & $\mathrm{FF}$ & $\eta(\%)$ & $R_{1}\left(\Omega \mathrm{cm}^{2}\right)$ & $R_{2}\left(\Omega \mathrm{cm}^{2}\right)$ & $R_{3}\left(\Omega \mathrm{cm}^{2}\right)$ & $\tau(\mathrm{ms})$ \\
\hline $\mathrm{a}$ & 16.65 & 0.568 & 0.49 & 4.70 & 21.55 & 4.39 & 13.22 & 14.09 \\
\hline $\mathrm{b}$ & 16.69 & 0.563 & 0.48 & 4.58 & 20.03 & 4.71 & 14.88 & 25.21 \\
\hline c & 15.27 & 0.545 & 0.51 & 4.26 & 22.23 & 6.24 & 11.23 & 19.61 \\
\hline d & 14.71 & 0.528 & 0.50 & 3.90 & 20.15 & 7.44 & 7.96 & 6.41 \\
\hline $\mathrm{e}$ & 11.30 & 0.596 & 0.45 & 3.01 & 20.96 & 37.06 & 31.03 & 0.12 \\
\hline
\end{tabular}



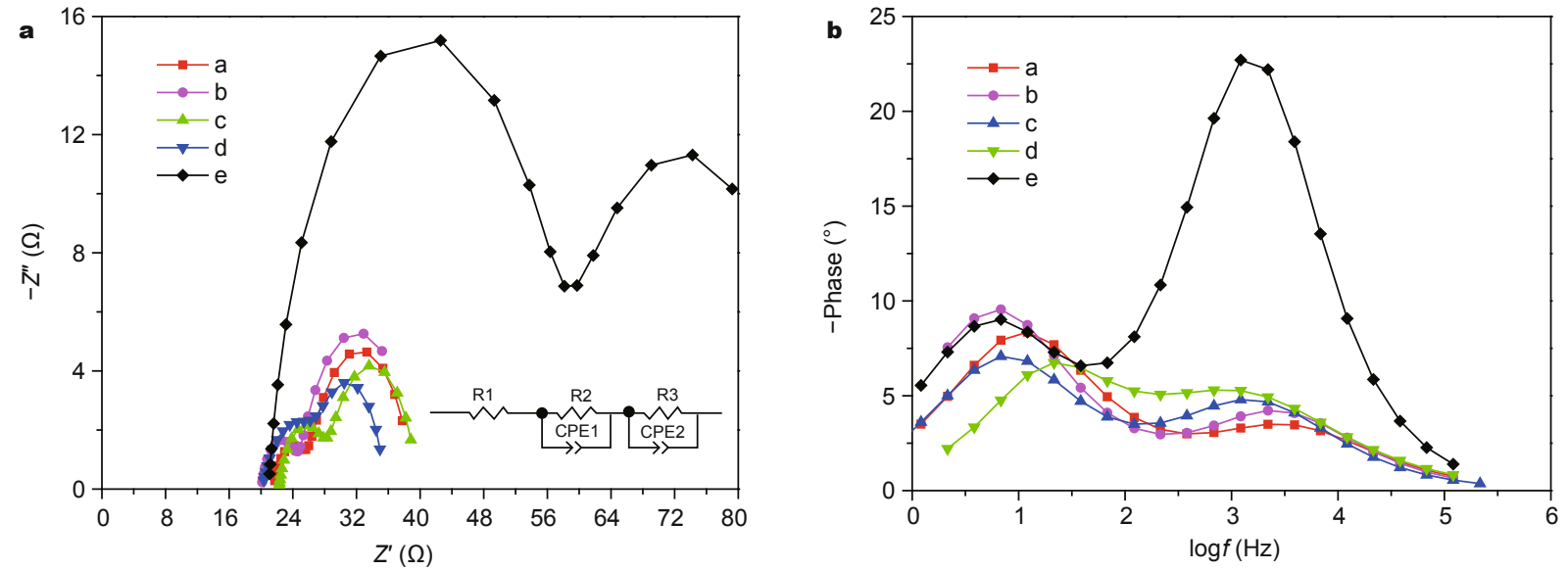

Figure 2 Electrochemical impedance curves of the solar cells containing the same photoanode, same CEs, and electrolytes a, b, c, d, and e: (a) Nyquist plots; (b) Bode phase plots.

hance the electrolyte performance and perform CV measurements. Fig. 3 shows the CV curves obtained in electrolyte a with and without $0.05 \mathrm{M}$ DMPII. The cathodic peak current increases in Fig. 3 with the addition of DMPII. This new electrolyte with DMPII was then used for the assembly of QDSSCs with a CdS/CdSe co-sensitized $\mathrm{TiO}_{2}$ photoelectrode and a PbSe $\mathrm{CE}$, and $J-V$ curves were measured for these cells (Fig. 4). As expected, the DMPII containing electrolyte shows a significant increase in efficiency compared to that with electrolyte a alone. Also, a higher dark current implies a higher probability for the charge recombination at the electrode/electrolyte interface [28]. The addition of DMPII effectively prevents these unwanted recombination processes and enhances the electrolyte's electrochemical properties. EIS measurements of the electrolyte containing DMPII were performed in the dark (Fig. $5)$. Calculated dark values of $J_{\mathrm{sc}}, V_{\mathrm{oc}}, \eta, \mathrm{FF}$, resistances $\left(R_{1}\right.$, $\left.R_{2}, R_{3}\right)$, and electron recombination lifetimes $(\tau)$ are listed

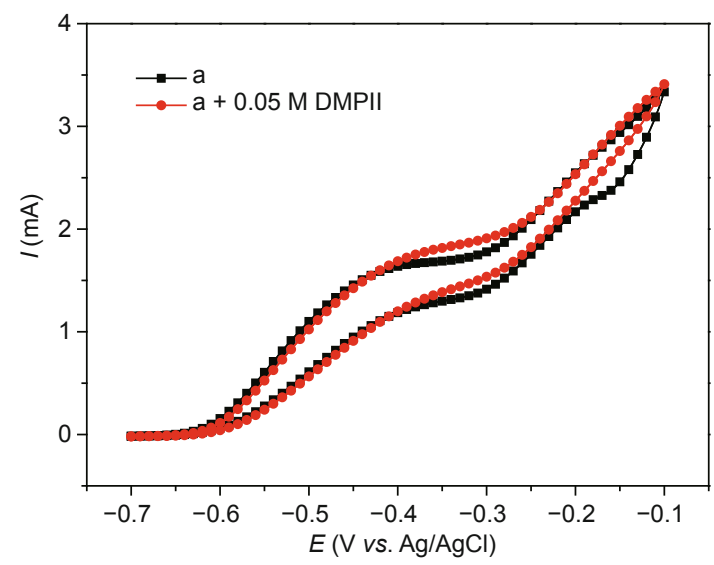

Figure 3 Cyclic voltammograms of the electrolytes at a scan rate of 50 $\mathrm{mV} \mathrm{s}^{-1}$.

in Table 3. The electrolyte with DMPII possesses a longer electron recombination lifetime than electrolyte a alone.
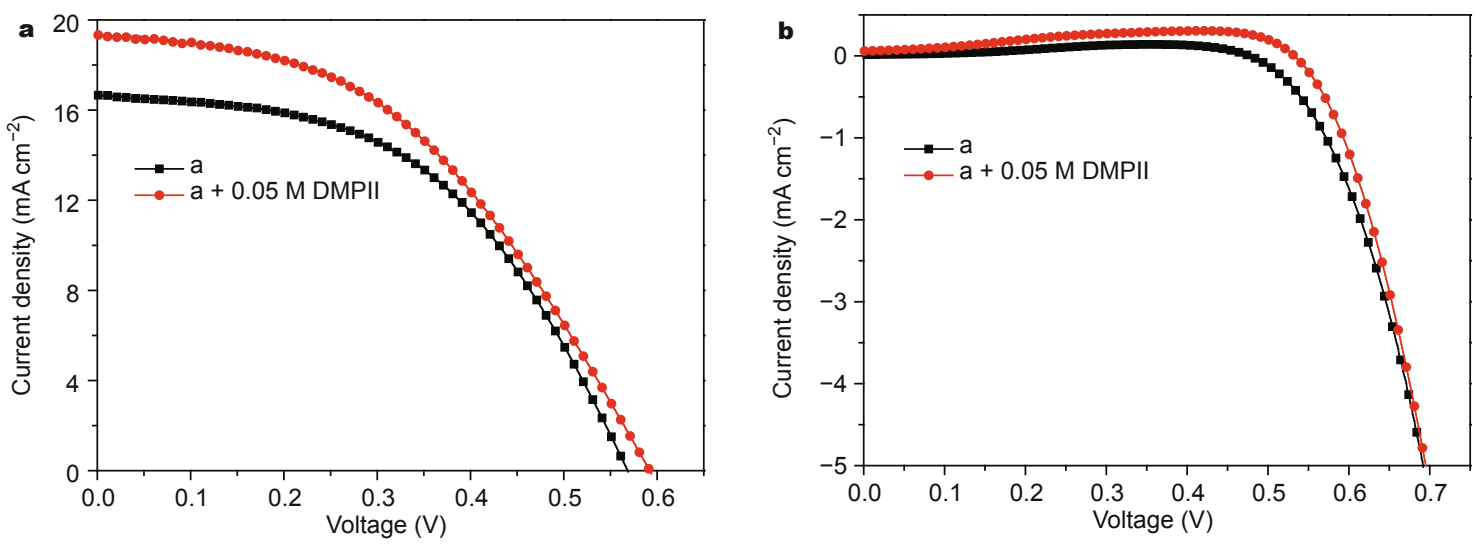

Figure 4 Photocurrent density-voltage $(J-V)$ of the new electrolyte (a) under one-sun illumination and (b) in dark condition. 

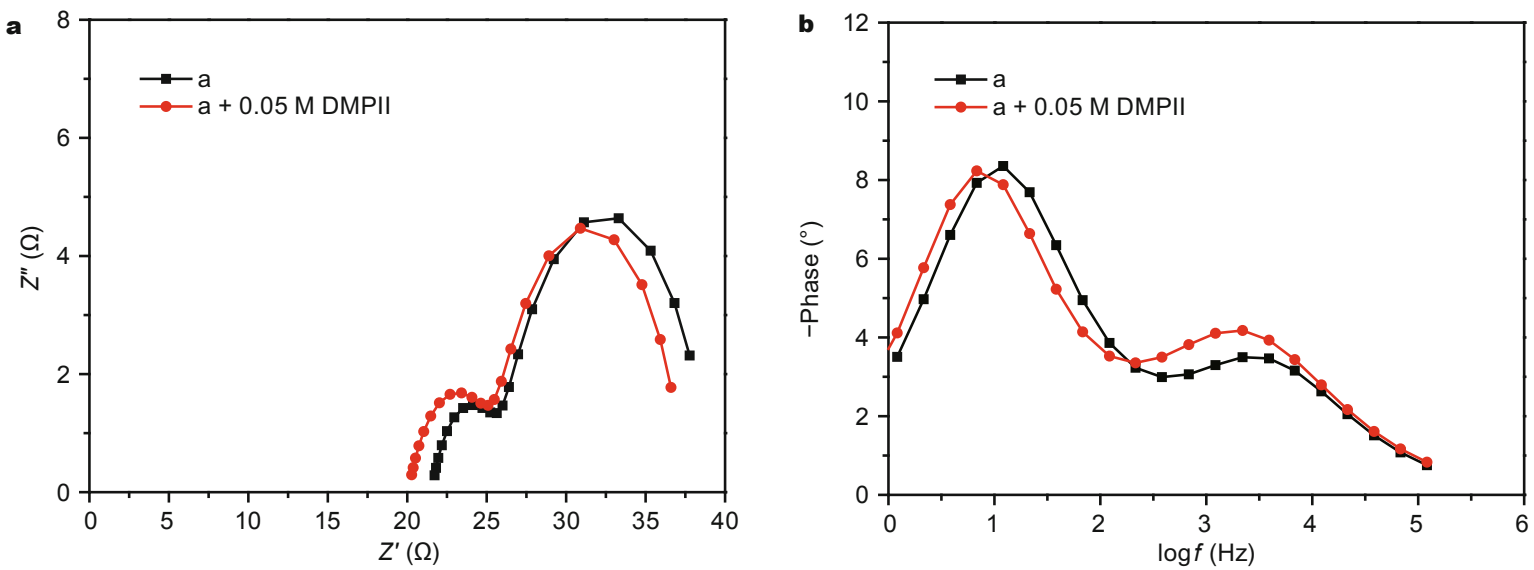

Figure 5 Electrochemical impedance spectra of electrolyte a and electrolyte a + 0.05 M DMPII: (a) Nyquist plots; (b) Bode phase plots.

Table 3 Photovoltaic performance of CdS/CdSe co-sensitized $\mathrm{TiO}_{2}$ film and PbSe CE with the electrolyte a and $0.05 \mathrm{M}$ DMPII added into the electrolyte a

\begin{tabular}{lcccccccc}
\hline Electrolyte & $J_{\mathrm{sc}}\left(\mathrm{mA} \mathrm{cm}^{-2}\right)$ & $V_{\mathrm{oc}}(\mathrm{V})$ & $\mathrm{FF}(\%)$ & $\eta(\%)$ & $R_{1}\left(\Omega \mathrm{cm}^{2}\right)$ & $R_{2}\left(\Omega \mathrm{cm}^{2}\right)$ & $R_{3}\left(\Omega \mathrm{cm}^{2}\right)$ & $\tau(\mathrm{ms})$ \\
\hline $\mathrm{a}$ & 16.65 & 0.568 & 0.49 & 4.70 & 21.55 & 4.39 & 13.22 & 14.09 \\
$\mathrm{a}+0.05$ M DMPII & 19.36 & 0.592 & 0.45 & 5.14 & 20.08 & 5.59 & 11.79 & 23.23 \\
\hline
\end{tabular}

\section{CONCLUSIONS}

In summary, we demonstrated direct connection between the photocurrent density achieved in QDSSCs and the cathodic peak current measured by $\mathrm{CV}$ using the same electrolyte. Electrolytes with different compositions were characterized to validate and demonstrate this facile, new evaluation method. Using this intuitive approach, we synthesized a novel electrolyte and built a QDSSC based on the $\mathrm{CdS} / \mathrm{CdSe}$ co-sensitized $\mathrm{TiO}_{2}$ photoelectrode and $\mathrm{PbSe}$ $\mathrm{CE}$ with a power conversion efficiency of $5.14 \%$ under one sun illumination. Although only a limited number of electrolytes have been studied to date, more additives will be tested for the optimization of QDSSC performance in the future. Furthermore, more extensive testing is ongoing to demonstrate the predictive capability of CV measurements for the selection of electrolytes for QDSSCs.

\section{Received 7 May 2015; accepted 26 May 2015;} published online 5 June 2015

1 Kamat PV. Quantum dot solar cells. Semiconductor nanocrystals as light harvesters. J Phys Chem C, 2008, 112: 18737-18753

2 Yang Z, Chen CY, Roy P, et al. Quantum dot-sensitized solar cells incorporating nanomaterials. Chem Commun, 2011, 47: 9561-9571

3 Han L, Wang YF, Zeng JH. Effectives solid electrolyte based on benzothiazolium for dye-sensitized solar cells. ACS Appl Mater Interfaces, 2014, 6: 22088-22095

4 Hodes G, Manassen J. Electrocatalytic electrodes for the polysulfide redox system. J Electrochem Soc, 1980, 127: 544-549

5 Cong JY, Yang XC, Hao Y, et al. A highly efficient colorless sulfur/ iodide-based hybrid electrolyte for dye-sensitized solar cells. RSC Adv, 2012, 2: 3625-3629

6 Shalom M, Dor S, Ruhle S, et al. Core/CdS quantum dot/shell mesoporous solar cells with improved stability and efficiency using an amorphous $\mathrm{TiO}_{2}$ coating. J Phys Chem C, 2009, 113: 3895-3898

7 Sero IM, Bisquert J. Breakthrough in the development of semiconductor-sensitized solar cells. J Phys Chem Lett, 2010, 1: 3046-3052

8 Park S, Son MK, Kim SK, et al. The effects of electrolyte additives on the cell performances of $\mathrm{CdS} / \mathrm{CdSe}$ quantum dot sensitized solar cells. Korean J Chem Eng, 2013, 30: 2088-2092

9 Li L, Yang XC, Gao JJ, et al. Highly efficient CdS quantum dot-sensitized solar cells based on a modified polysulfide electrolyte. J Am Chem Soc, 2011, 133: 8458-8460

10 Sero IM, Gimenez S, Moehl T, et al. Factors determining the photovoltaic performance of a CdSe quantum dot sensitized solar cell: the role of the linker molecule and of the counter electrode. Nanotechnology, 2008, 19: 1-7

11 Zhang QX, Zhang YD, Huang SQ, et al. Application of carbon counterelectrode on CdS quantum dot-sensitized solar cells(QDSSCs). Electrochem Commun, 2010, 12: 327-330

12 Jovanocski V, Pedro VG, Gimenez S, et al. A sulfide/polysulfide-based ionic liquid electrolyte for quantum dot-sensitizes solar cells. J Am Chem Soc, 2011, 133: 20156-20159

13 Yang Z, Chen CY, Liu CW, et al. Electrocatalytic sulfur electrodes for CdS/CdSe quantum dot-sensitized solar cells. Chem Commun, 2010, 46: 5485-5487

14 Chen J, Lei W, Deng WD. Reduced charge recombination in a co-sensitized quantum dot solar cell with two different sizes of CdSe quantum dot. Nanoscale, 2011, 3: 674-677

15 Zhu G, Su FF, Lv T, et al. Au nanoparticles as interfacial layer for CdS quantum dot-sensitized solar cells. Nanoscale Res Lett, 2010, 5: $1749-1754$

16 Seo H, Ichida D, Uchida G, et al. Performance dependence of Si quantum dot-sensitized solar cells on counter electrode. Jpn J Appl 
Phys, 2014, 53: 1-4

17 Yang Z, Chen CY, Liu CW, et al. Quantum dot-sensitized solar cells featuring $\mathrm{CuS} / \mathrm{CoS}$ electrodes provide $4.1 \%$ efficiency. Adv Energy Mater, 2011, 1:259-264

18 Li CH, Yang L, Xiao JY, et al. ZnO nanoparticle based highly efficient CdS/CdSe quantum dot-sensitized solar cell. Phys Chem Chem Phys, 2013, 15: 8710-8715

19 Kim BM, Son MK, Kim SK, et al. Improved performance of CdS/ CdSe quantum dot-sensitized solar cells using Mn-doped PbS quantum dots as a catalyst in the counter electrode. Electrochimica Acta, 2014, 117: 92-98

20 Choi HM, Ji IA, Bang JH. Metal selenides as a new class of electrocatalysts for quantum dot-sensitized solar cells: a tale of $\mathrm{Cu}_{1.8} \mathrm{Se}$ and PbSe. ACS Appl Mater Interfaces, 2014, 6: 2335-2343

21 Gaddie RS, Moss CB, Elliott CM. Cyclic voltammetric study of cobalt poly-4-t-butylpyridine ligand complexes on glassy carbon electrodes: electrolyte dependence and mechanistic considerations. Langmuir, 2013, 29: 825-831

22 Ganapathy V, Kong EH, Park YC, et al. Cauliflower-like $\mathrm{SnO}_{2}$ hollow microspheres as anode and carbon fiber a cathode for high performance quantum dot and dye-sensitizes solar cells. Nanoscale, 2014, 6: 3296-3301

23 Zhang JB, Zhao FY, Tang GS, et al. Influence of highly efficient PbS counter electrode on photovoltaic performance of CdSe quantum dots-sensitized solar cells. J Solid State Electrochem, 2013, 17: 2909-2915
24 Guo WX, Chen C, Ye MD, et al. Carbon fiber/ $\mathrm{Co}_{9} \mathrm{~S}_{8}$ nanotube arrays hybrid structures for flexible quantum dot-sensitized solar cells. Nanoscale, 2014, 6: 3656-3663

25 Raj CJ, Prabakar K, Savariraj AD, et al. Surface reinforced platinum counter electrode for quantum dots sensitized solar cells. Electrochimica Acta, 2013, 103: 231-236

26 Cui XR, Wang YF, Li Z, et al. Micrometer-sized fluorine doped tin oxide as fast electron collector for enhanced dye-sensitized solar cells. ACS Appl Mater Interfaces, 2014, 6: 16593-16600

27 Yeh MH, Lin LY, Lee CP, et al. High performance CdS quantum-dot-sensitized solar cells with Ti-based ceramic as catalysts on the counter electrode. J Power Sources, 2013, 237: 141-148

28 Chong LW, Chien HT, Lee YL. Assembly of CdSe onto mesoporous $\mathrm{TiO}_{2}$ films induced by a self-assembled monolayer for quantum dot-sensitized solar cell applications. J Power Sources, 2010, 195: 5109-5113

Acknowledgments This work was supported by the National Natural Science Foundation of China (51278034).

Author contributions Ren F and Li S designed and performed the experiments. Li S performed the experiments and the data analysis. $\mathrm{He} \mathrm{C}$ performed experiments using $\mathrm{CV}$ measurement. Ren $\mathrm{F}$ wrote the paper. All authors contributed to the general discussion and writing.

Conflict of interest The authors declare that they have no conflict of interest.

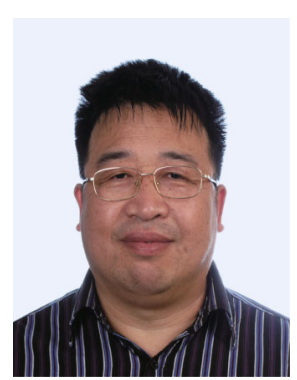

Fumin Ren is an associate professor of the Department of Municipal and Environment Engineering, Beijing Jiaotong University (BJTU). He got his PhD degree from BJTU in 2002, MSc degree in material science from the School of Chemistry and Materials Science, University of Science and Technology of China in 1991, and BSc degree from the Department of Chemistry, Zhengzhou University in 1987. His research focuses on the environmental materials, the electrolyte of quantum dot-sensitized solar cells, atmospheric environment, and the theory of transportation environment.

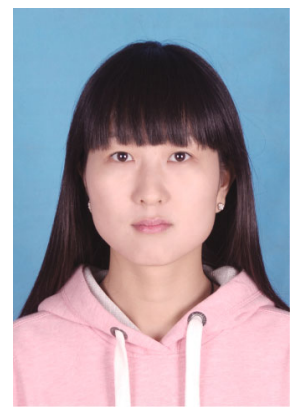

Sujun $\mathrm{Li}$ is currently a postgraduate student at BJTU. She is majoring in environmental engineering. She got her BSc degree from the Department of Civil Engineering, Xi' an University of Science and Technology in 2012. Her research focuses on the electrolyte of quantum dot-sensitized solar cells, and the treatment of heavy metal in sewage sludge.

中文摘要 本文阐述了一种直观判断量子点敏化太阳能电池电解液性能的方法. 采用由工作电极、对电极和参比电极组成的标准三电 极系统, 扫描速度为 $50 \mathrm{mV} \mathrm{s}^{-1}$, 在 $-0.7 \sim-0.1 \mathrm{~V}$ 的电压范围内对五种不同的多硫电解液进行循环伏安法测定. CV曲线中还原峰电流越 高, 表明氧化还原反应速率越快 $\left(\mathrm{S}_{n}^{2-}\right.$ to $\left.\mathrm{S}^{2-}\right)$. 本文所采用的量子点敏化太阳能电池由 CdS/CdSe共敏化的光阳极、 $\mathrm{PbSe}$ 对电极以及多硫 电解液为主要结构组成, 测量了光电流密度和电压的曲线. 能量转换效率所显示的结果与 CV结果一致. 添加 $0.05 \mathrm{M}$ 的1,2-二甲基-3-丙 基咪唑碘盐后的量子点敏化太阳能电池转换效率为 $5.14 \%$. 